\begin{tabular}{|l|l|l||}
\hline \multicolumn{2}{|c|}{ PublisherInfo } \\
\hline \hline PublisherName & $:$ & BioMed Central \\
\hline \hline PublisherLocation & $:$ & London \\
\hline \hline PublisherImprintName & $:$ & BioMed Central \\
\hline \hline
\end{tabular}

\title{
Genomic mountains
}

\begin{tabular}{|l|l|l||}
\hline \multicolumn{2}{|c|}{ ArticleInfo } \\
\hline \hline ArticleID & $:$ & 4204 \\
\hline \hline ArticleDOI & $:$ & $10.1186 /$ gb-spotlight-20010919-02 \\
\hline \hline ArticleCitationID & $:$ & spotlight-20010919-02 \\
\hline \hline ArticleSequenceNumber & $:$ & 275 \\
\hline \hline ArticleCategory & $:$ & Research news \\
\hline \hline ArticleFirstPage & $:$ & 1 \\
\hline \hline ArticleLastPage & $:$ & 2 \\
\hline \hline & & RegistrationDate : 2001-09-19 \\
ArticleHistory & $:$ & OnlineDate \\
\hline \hline ArticleCopyright & $:$ & BioMed Central Ltd2001 \\
\hline \hline ArticleGrants & $:$ & \\
\hline \hline ArticleContext & $:$ & 130592211 \\
\hline \hline
\end{tabular}




\section{Jonathan B Weitzman}

Email: jonathanweitzman@hotmail.com

One of the challenges for microarray analysis is making sense of the mountains of data that this technology can generate. In the September 14 Science, Stuart Kim and colleagues from Stanford University show how three-dimensional maps can be used to navigate microarray data (Science 2001, 293:2087-2092). They established a compendium of gene expression profiles for the Caenorhabditis elegansgenome using data from 553 microarray experiments. They created topological maps in which distance defines correlations in gene expression profiles and the height of each mountain (43 in total) reflects clustering of gene density. The data come from microarray analysis of multiple mutant strains and different growth conditions. Each mountain contains sets of highly correlated genes, reflecting biological function (such as tissue distribution or cellular activity). Navigating this genomic terrain will provide new insights into gene function and biological processes.

\section{References}

1. Science, [http://www.sciencemag.org]

2. Stanford University, [http://www.stanford.edu]

3. Genome sequence of the nematode C. elegans: a platform for investigating biology. 